\title{
PCR Based Screening of Fusarium sp. in some Organic Products
}

\author{
Oana M. BOLDURA*, Petrica BOZAC, Sorina POPESCU \\ Banat University of Agricultural Sciences and Veterinary Medicine "Regele Mihai I al Romaniei" \\ Timisoara, Romania \\ *Corresponding author, e-mail: oanaboldura@gmail.com
}

Bulletin UASVM Animal Science and Biotechnologies 72(1) / 2015

Print ISSN 1843-5262; Electronic ISSN 1843-536X

DOI:10.15835/buasvmcn-asb:10753

\begin{abstract}
In the past few decades the issue of healthy, organic food has become of great importance among consumers and therefore food producers. It is the age of ecological food with the challenge of producing ecological crops. Fungi are of importance for human and animal health because of their ability to produce mycotoxin. The aim of our work was to develop a rapid, cost efficient method of identifying the fungal infection in different ecological products by using PCR screening methods. In this purpose 18 ecological products meaning seeds and flours, designated to be aliments or ingredients to different cosmetically products were purchased. DNA was isolated from collected samples and control. The screening was performed by PCR method using 4 specific primer pairs. In order to determine if the DNA suspension is proper for to be used, the samples were amplified with the specific primers for the ribulose-1,5-bisphosphat carboxylase gene (RuBisCo). Further on, the screening was performed for the presence of Fusarium and for 4 specific species of that genus. All the samples were positive for the presence of Fusarium genus DNA. The screen pointed out that from 12 screened samples five were positive for $F$. graminearum, two were positive for F. culmorum, five were positive for F. proliferatum, four were positive for F. verticiloides and for 6 the specie of fungus was not identified. With the present work we emphasized another issue that must be taken into account when the safety of these products is evaluated.
\end{abstract}

Keywords: organic products, DNA, Fusarium genus, specific primers, PCR screening

\section{INTRODUCTION}

In present time we are witnessing an increasing trend of consumption of products labeled as organic, these products are free from any synthetic chemicals intervention throughout the stages of vegetation. Including in cosmetics, natural ingredients, organic products have gained much ground, although their price is higher than conventional products. On the other hand, homemade cosmetic recipes entered the consumer preferences. Consumers prefer to avoid the fungicide residues but are not warned of risks becoming from residuals fungal infections.

Mycotoxin absorption usually occurs through ingesting contaminated food, inhalation but also through dermal exposure to various contaminants such as air or different products for skin application (Boonena et al., 2012). Mayer et al. (2007) identified the need for studies regarding the modality of exposure to mycotoxins.

Framed as a kingdom separate from that of bacteria, plants and animals, the kingdom Fungi includes yeasts, molds and fungi. Elite decomponants, with cosmopolitan spreading fungi have an essential role in ecosystems on Earth, two thirds of the plants being involved in symbiotic relationships with various fungi. Of the 100,000 classified species, 400 species are pathogenic for plants, animals and humans, a small number compared to the vast majority. Despite measures to control diseases in crops promoted by the Green Revolution, the damage caused by phytopathogenic fungi rise up to the hundreds of billions of Euros annually (Windels, 2000). 
Tab. 1. Biological samples used in this study.

In a ranking of the most devastating fungi, conducted by nearly 500 professionals worldwide, fourth and fifth places are occupied by fungi of the genus Fusarium (Dean et al., 2012).

Mycotoxins produced by different fungi are so called "natural killers ". Mycoses are the most common diseases of fungal etiology, but secondary metabolites produced by saprophytic species are also a major health hazard. Mycotoxins produced by Fusarium sp., particularly deoxynivalenol and zearalenone, are considered contaminants of food. Some mycotoxins are highly toxic to the liver, other to kidney, reproductive system, central nervous system or circulatory system. Behind infection with Fusarium sp. in grains there is actually a complex of several species, about 19 (Liddell, 2003), species which have large differences in the morphology (Leslie and Summerell, 2006), the profile of mycotoxins (Logrieco et al., 2002), environmental preferences (Xu et al., 2008), host preferences (Simpson et al., 2000; Boutigny et al., 2011).

Considering all these issues, this research aims to investigate products that can be used as food and for skin care, labeled as organic, on the local market for the infestation with mycotoxin producing fungal strains, proposing the following objectives: Identification of the main species of Fusarium present in the studied products and: The use of biomolecular techniques by which to identify unambiguously and in a short time the presence of pathogenic strains.

\section{MATERIALS AND METHODS}

Biological material, on which the experiments were conducted, is represented by vegetal products labeled as organic, mainly raw materials used in food and cosmetics. Samples for analysis were purchased from the local market in organic food stores (Tab. 1).

DNA extraction. For concentration of oil samples, Wizard $₫$ Magnetic DNA Purification System for Food, (Promega U.S.A), kit was used. $300 \mu \mathrm{l}$ of resulting aqueous solution was used as matrix in the following DNA extraction protocol. For DNA extraction CTAB method (ISO 21571, 2005), wich is suitable for a wide category of matrixes, was used. The quality and quantity of obtained DNA was assessed using NanoDrop spectrophotometer (Thermo Scientific, USA).

\begin{tabular}{cccc}
\hline No. & Analyzed product & No. & Analyzed product \\
\hline 1 & Oat bran & 10 & Virgin olive oil \\
\hline 2 & Rye bran A & 11 & Olive oil B \\
\hline 3 & Wheat bran A & 12 & Sun flower seeds \\
\hline 4 & Wheat bran B & 13 & Peanuts \\
\hline 5 & Corn flour A & 14 & Pumpkin seeds \\
\hline 6 & Olive oil A & 15 & Alimentary pasta A \\
\hline 7 & Corn flour B & 16 & Alimentary pasta B \\
\hline 8 & Rye bran A & 17 & $\begin{array}{c}\text { Oat biscuits with } \\
\text { candied fruit }\end{array}$ \\
\hline 9 & Wheat bran C & 18 & Wheat biscuits \\
\hline
\end{tabular}

PCR assays. Amplificable quality of DNA was confirmed by PCR technique, using RuBisCo primers, witch amplify cromosomal regions that are specific to any vegetal genome:

CW:5'-CGTAGCTTCCGGTGGTATCCACGT-3', CX: 5'-GGGGCAGGTAAGAAAGGGTTTCGTA-3'

For identification of Fusarium and different species of this fungus the following primers were used:

\begin{tabular}{|c|c|c|}
\hline Species & Primers sequence & $\begin{array}{l}\text { Amplicon } \\
\text { size (bp) }\end{array}$ \\
\hline $\begin{array}{l}\text { Fusarium } \\
\text { spp./region } \\
\text { TEF }\end{array}$ & $\begin{array}{l}\text { 5' } \text { ATGGGTAAGGAGGACAAGAC }^{3^{\prime}} \\
\text { 3' GGAAGTACCAGTGATCATGTT }^{5^{\prime}}\end{array}$ & 760 \\
\hline $\begin{array}{l}\text { Fusarium } \\
\text { graminearum } \\
\text { Fgr-F/Fgr-R }\end{array}$ & $\begin{array}{l}5^{5}{ }^{\prime} \text { TCCGGATATGTTGCGTCAA }{ }^{3^{\prime}} \\
{ }^{5} \text { GGTAGGTATCCGACATGGCAA }^{3^{\prime}}\end{array}$ & 450 \\
\hline $\begin{array}{l}\text { Fusarium } \\
\text { culmorum } \\
F c-R / F_{C}-F\end{array}$ & $\begin{array}{l}\text { 5'ATGGTGAACTCGTCGTGGC }{ }^{3^{\prime}} \\
{ }^{5} \text { CCCTTCTTACGCCAATCTCG }^{3^{\prime}}\end{array}$ & 570 \\
\hline $\begin{array}{l}\text { Fusarium } \\
\text { proliferatum }\end{array}$ & $\begin{array}{l}{ }^{5^{\prime}} \text { CGGCCACCAGAGGATGTG }{ }^{3^{\prime}} \\
3^{\prime} \text { CAACACGAATCGCTTCCTGAC }^{5^{\prime}}\end{array}$ & 230 \\
\hline $\begin{array}{l}\text { Fusarium } \\
\text { verticilloides }\end{array}$ & $\begin{array}{l}5^{5^{\prime}} \text { CGCACGTATAGATGGACAAG }^{3^{\prime}} \\
3^{\prime} \text { CACCCGCAGAATCCATCCATCAG }^{5^{\prime}}\end{array}$ & 700 \\
\hline
\end{tabular}

In all cases, amplification reactions were carried out in volumes of $25 \mu \mathrm{l}$ containing $25 \mathrm{ng}$ of DNA template. The composition of amplification mixture was carried out following the producer instructions for KAPA2G RobustHotStart ReadyMix (KAPA BIOSYSTEMS, Boston, USA). PCR was performed on a Mastercycler ProS (Eppendorf 
U.S.) and the PCR program consisted of an initial denaturing step for $5 \mathrm{~min}$ at $95^{\circ} \mathrm{C}$, followed by 30 cycles of denaturation at $95^{\circ} \mathrm{C}$ for $45 \mathrm{sec}$, annealing at $55^{\circ} \mathrm{C}-60^{\circ} \mathrm{C}$ for $45 \mathrm{sec}$ and extension at $72^{\circ} \mathrm{C}$ for $2 \mathrm{~min}$, with a final step at $72^{\circ} \mathrm{C}$ for 3 min., according to literature data (Sampietro et al., 2010.) The resulting PCR products were run on $2 \%$ agarose gels in TAE buffer at room temperature at a constant voltage of $100 \mathrm{~V}$ for 40 minutes. The positive control was represented by DNA extracted from pure fungal culture. For negative control, PCR water was used. The PCR products were visualized and photographed under UV light (PhotoDocumentation System, UVP, England).

\section{RESULTS AND DISCUSSION}

The firststage consisted of preparing biological material for DNA extraction. For concentration of oil samples a commercial kit was used according to the manufacturer instructions after which 300 $\mu \mathrm{l}$ aqueous solution was used as matrix for DNA extraction protocol.
In the case of solid consistency material it was procceeded to grinding to obtain homogeneous samples, after which the tubes were weighed in amounts of $100 \mathrm{mg}$. The corn flour was passed directly to the weighing of test material in tubes. For each test sample the DNA was extracted, whose concentration was determined by spectrophotometric method. At the same time the absorbance ratio A 260/280 was determined (Tab. 2).

It can be noticed that overall the quality of samples was appropriate, OD 260/280 ratio hovering around 1.8-2.2. In the case of oil the initial purification has been used successfully, producing quality amplified DNA. The obtained results allowed the PCR analysis, both in terms of quantity and quality of the isolated DNA. In order that the template DNA to be at the same concentration for all samples, dilutions were carried out so that each sample to achieve a concentration of $25 \mathrm{ng} / \mu \mathrm{l}$. Further, all DNA samples were amplified with specific primers for ribulose-bisphosphate carboxylase-1.5

Tab. 2. Concentration and quality of DNA isolated from biological material.

\begin{tabular}{cccc}
\hline No. & Analyzed product & Concentration $\mathbf{n g} / \boldsymbol{\mu l}$ & $\mathbf{A 2 6 0 / 2 8 0}$ \\
\hline 1 & Oat bran & 412.5 & 2.06 \\
\hline 2 & Rye bran A & 484.6 & 2.07 \\
\hline 3 & Wheat bran A & 429.0 & 1.82 \\
\hline 4 & Wheat bran B & 389.4 & 1.99 \\
\hline 5 & Corn flour A & 546.7 & 1.91 \\
\hline 6 & Olive oil A & 34.6 & 2 \\
\hline 7 & Corn flour B & 521.5 & 2.04 \\
\hline 8 & Rye bran A & 468.4 & 1.98 \\
\hline 9 & Wheat bran C & 476.7 & 2.05 \\
\hline 10 & Virgin olive oil & 29.3 & 2.12 \\
\hline 11 & Olive oil B & 32.58 & 2.1 \\
\hline 12 & Sun flower seeds & 26.7 & 2.1 \\
\hline 13 & Peanuts & 25.9 & 2 \\
\hline 14 & Pumpkin seeds & 28.4 & 1.94 \\
\hline 15 & Alimentary pasta A & 371.1 & 2.14 \\
\hline 16 & Alimentary pasta B & 354.7 & 2.15 \\
\hline 17 & Oat biscuits with candied fruit & 156 & 2.2 \\
\hline 18 & Wheat biscuits & 128.4 & 2.1 \\
\hline & & & \\
\hline
\end{tabular}


(RuBisCo) gene. This is a reference gene, present in all plant cells. Highlighting this gene in a DNA sample extracted from the studied products is proof of vegetable origin and amplifying quality of this DNA sample. The amplification products corresponding to each sample were analyzed by agarose gel electrophoresis (Fig. 1). Bands of expected size are observable for all samples and its absence in case of negative controls.

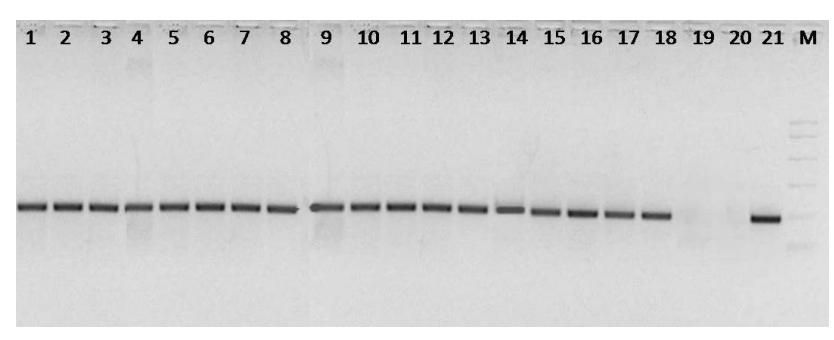

Fig. 1. Agarose gel elecrophoresis of amplification reaction products, specific for ribulose-1,5-bisphosphat carboxylase (RuBisCo) gene : 1 . Oat bran; 2 . Rye bran A; 3 . Wheat bran A; 4. Wheat bran B; 5. Corn flour A; 6. Olive oil A ; 7. Corn flour B; 8. Rye bran B; 9. Wheat bran C; 10. Virgin olive oil; 11. Olive oil B; 12 .Sun flower seeds; 13 . Peanuts; 14. Pumpkin seeds; 15 . Alimentary pasta A; 16 . Alimentary pasta B ; 17. Oat biscuits with candied fruit; 18. Wheat Biscuits; 19. Negative control - DNA of animal origin; 20. Reagents control; 21. Positive control - DNA of vegetal origin M - DNA ladder PCR marker (Promega).

Inthe nextstepthe DNA sampleswereamplified with specific primers for Fusarium spp. namely oligonucleotides sequences complementary to TEF sequence used to identify species belonging to genus Fusarium (Fig. 2). The presence of this amplification product with a molecular weight of about $500 \mathrm{bp}$, is confirming the presence of infection in various species of the genus Fusarium in all samples analyzed. Differences between bands intensity are the proof of the level of contamination. It is worth mentioning that none of the analyzed samples was found to be free of fungal infections. The most obvious infestations are to be observed in case of samples 3 (wheat bran A), 9 (wheat bran C) and 14 (pumpkin seeds).

Because our collection of primers for Fusarium genus does not contains those specific for matrices like olive, sun flower, peanuts and pumpkin further we screened only samples containing grain ingredients. F. graminearum is recognized as the most common species of this kind the first screening was performed using primers specific for this species (Fig 3, panel A). Agarose gel

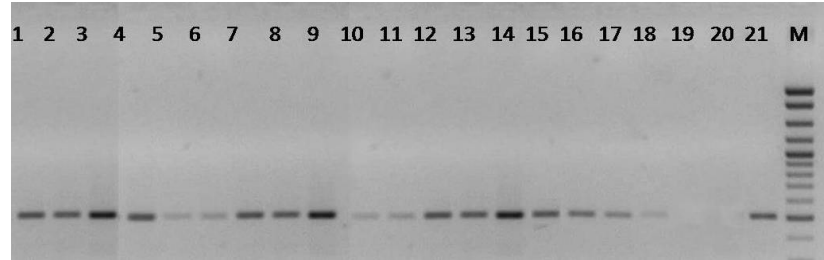

Fig. 2. Agarose gel elecrophoresis of amplification reaction products, specific for Fusarium spp. gennus: 1 . Oat bran; 2. Rye bran A; 3. Wheat bran A; 4. Wheat bran B; 5. Corn flour A; 6. Olive oil A; 7. Corn flour B; 8. Rye bran B; 9. Wheat bran $C ; 10$. Virgin olive oil; 11 . Olive oil B; 12 .Sun flower seeds; 13 . Peanuts; 14. Pumpkin seeds; 15. Alimentary pasta A; 16 . Alimentary pasta B ; 17 . Oat biscuits with candied fruit; 18. Wheat Biscuits; 19. Negative control - DNA of animal origin; 20. Reagents control; 21. Positive control - DNA of Fusarium origin; M - DNA ladder, CloneSizer (Norgen Biotek).

analysis reveals the presence of $F$ graminearum in samples of wheat bran $\mathrm{A}$ and $\mathrm{B}(3$ and 4$)$ corn flour B (6), rye bran (7) and wheat biscuits (12), demonstrated by the appearance of a $450 \mathrm{bp}$ band . Although the intensity of the band corresponding to amplicon is sufficiently intense to identify $F$. graminearum, they did not exceed the intensity of control sample. Five of the 12 samples analyzed were found to be positive $F$ graminearum.

Next screening was performed using specific primers for Fusarium culmorum specie. In this case the presence of a band having the size of 570 $\mathrm{bp}$, means confirmation of material infected with F. culmorum. Analyzing the image, it can be noticed that the species F. culmorum, is present in two of the samples analyzed: 5 and 6, corn flour A and B (Fig. 3, panel B). Infection with this pathogen is quite rare in our country, especially in the western area where climatic conditions are unfavorable to the development of this fungus. Therefore, it is likely that the raw materials of those products have originated in other areas.

For the following screening specific primers for Fusarium proliferatum was carried out. F. proliferatum is a species belonging to the genus Fusarium being specific to maize. In this case the presence of a band having the size of $230 \mathrm{bp}$, means confirmation of material infected with $F$. proliferatum. Gel analysis reveals the presence of Fusarium proliferatum in oat bran (sample 1), rye bran A (sample 2) corn flour A (sample 5), alimentary pasta (sample 9), and in alimentary pasta (sample 10), as demonstrated by the appearance of the $230 \mathrm{bp}$ band (Fig. 3, panel C). In 


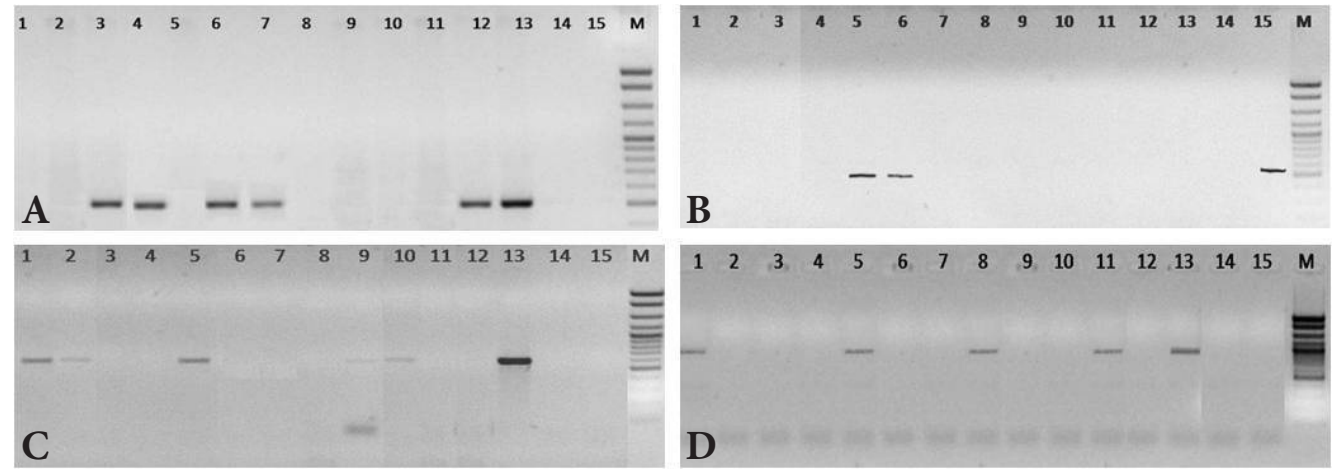

Fig. 3. Agarose gel elecrophoresis of amplification reaction products, specific for: A. Fusarium graminearum; B. Fusarium culmorum; C. Fusarium proliferatum; D. Fusarium verticilloides. 1 . Oat bran; 2. Rye bran A; 3 . Wheat bran A; 4 . Wheat bran B; 5. Corn flour A; 5. Corn flour A; 6. Corn flour B; 7. Rye bran B; 8. Wheat bran C; 9. Alimentary pasta A; 10. Alimentary pasta B ; 11. Oat biscuits with candied fruit; 12. Wheat Biscuits; 13. Positve control; 14. Negative control - DNA of animal origin; 15. Reagents control; M - DNA ladder, CloneSizer (Norgen Biotek).

case of samples 9 and 10, the intensity of the band is quite weak, to confirm the presence of the pathogen for which screening was conducted.

Next screening was performed using specific primers for Fusarium verticilloides specie, known to be present mainly in maize, although much less than the previous. In this case the presence of a band having the size of $700 \mathrm{bp}$, means confirmation of material infected with $F$. verticilloides. Image analysis reveals the presence of Fusarium verticilloides in oat bran samples (sample 1), corn flour A (sample 5), wheat bran C (sample 8) and oat biscuits with candied fruit (sample 11), shown by the appearance of a 700bp band.

Although the intensity of the band corresponding toamplicon is intense enough to affirm the presence of $F$. verticilloides, they did not exceed intensity of control sample. Four of the 12 analyzed samples were found to be positive for $F$. verticilloides. For sample 5 (corn flour A) it is the third identified infection here should being mentioned that the joining the three fungi in situ is extremely rare which means that a third outbreak occurred in the post-harvest period.

\section{CONCLUSION}

In the presented experiments the biological material was represented by samples labeled as organic, which at one time may become the consumer choice. Although, avoids hazards related to the use of chemicals, the consumer is hardly aware of the other risks faced by using natural products.

Regarding experimental model proposed in this paper following conclusions can be drawn.
DNA extraction method that was applied is appropriate and allows the analysis of different matrices (minimum concentration - $23.1 \mathrm{ng} / \mu \mathrm{l}$ ). The quality of DNA was proper, the ratio OD260 / 280 hovering around 1.8-2.2, which shows a corresponding purification of nucleic acids from analyzed samples.

All tested samples had amplification with primers specific to a plant gene (ribulosebisphosphate carboxylase-1.5, RuBisCo), thus obtained DNA was of amplificable quality, as was attested that all samples contained plant components

In the screening performed with primers specific to genus Fusarium no sample was found to be free of fungal DNA.

Fusarium graminearum was present in wheat, corn and rye samples.

Fusarium culmorum was identified in two corn samples.

Fusarium proliferatum is present in five samples: oat, rye, corn and both pasta.

Fusarium verticilloides was detected in four samples: two oat samples, corn and wheat.

\section{REFERENCES}

1. Boonena Jente, Svetlana V Malyshevab, Lien Taeverniera, Jose Diana Di Mavungub, Sarah De Saegerb, Bart De Spiegeleera (2012). Human skin penetration of selected model mycotoxins, Toxicology, 301, 21-32.

2. Boutigny AL, Ward J, Van Coller GJ, Flett B, Lamprecht SC, O'Donnell K, Viljoen A (2011). Analysis of the Fusarium graminearum species complex from wheat, barley, and maize in South Africa provides evidence of speciesspecific differences in host preference. Fungal Genet. Biol., 48, 914-920. 
3. Dean R, Van Kan JAL, Pretorius ZA, Hammond-Kosack KE, Di Pietro A, Spanu PD, Rudd JJ, Dickman M, Kahmann R, Ellis J \& Foster GD (2012). The Top 10 fungal pathogens in molecular plant pathology. Molecular Plant Pathology, 13 (4): 414-430.

4. Leslie JF, Summerell BA. (2006). The Fusarium Laboratory Manual Blackwell Publishing Ltd, Iowa.

5. Liddell CM (2003). Systematics of Fusarium species and allies associated with Fusarium head blight, Fusarium Head Blight of Wheat and Barley, APSPress, pp. 35-43, ISBN 0-89054-302-X, St. Paul, Minnesota, USA.

6. Logrieco A, A Bottalico, G Mulè, A Moretti and G Perrone (2003). Epidemiology of toxigenic fungi and their associated mycotoxins for some Mediterranean crops. Euro-pean Journal of Plant Pathology 109: 645-667.

7. Mayer S, Curtui V, Usleber E, Gareis M (2007). Airborne mycotoxins in dust from grain elevators, Mycotoxin Res. 23(2):94-100.
8. Sampietro DA, Marín P, Iglesias J, Presello DA, Vattuone MA, Catalan CAN, Gonzalez Jaen MT (2010). A molecular based strategy for rapid diagnosis of toxigenic Fusarium species associated to cereal grains from Argentina, Fungal Biology, Volume 114, Issue 1, January, 74-81.

9. Simpson DR, Rezanoor HN, Parry DW, Nicholson P (2000). Evidence for differential host preference in Microdochium nivale var. majus and Microdochium nivale var. nivale. Plant Pathol 49: 261-268.

10. Windels CE (2000). Economic and social impacts of Fusarium head blight: Changing farms and rural communities in the northern great plains. Phytopathology 90:17-21.

11. Xu X, Nicholson P, Thomsett MA, Simpson D, Cooke BM, Doohan FM, Brennan J, Monaghan S, Moretti A, Mule G, Hornok L, Beki E, Tatnell J, Ritieni A, Edwards SG, (2008). Relationship between the fungal complex causing Fusarium head blight of wheat and environmental conditions. Phytopathology 98: 69-78. 